\title{
Rasional Emotif Behavior Therapy (REBT) Islam Dalam Menumbuhkan Sikap Mental Positif
}

\author{
Hany Paturrochmah \\ Pascasarjana UIN Sunan Kalijaga Yogyakarta \\ hanyfaturrochamh@28gmail.com
}

\begin{abstract}
Abstrak
Penelitian ini bertujuan untuk mendeskripsikan teori REBT Islam dalam menumbuhkan sikap mental positif. Metode yang digunakan dalam penelitian ini menggunakan studi kepustakaan yang bersumber dari buku, artikel ilmiyah, website, serta hasil penelitian sebelumnya yang sejenis dan dapat digunakan untuk mendapatkan landasan teori mengenai masalah yang akan diteliti. Hasil analisis menjelaskan bahwa implementasi teori REBT yang terkandung dalam nilai Islam dapat menjadikan Individu memiliki kepribadian sehat dan akan menjadikan individu memiliki kepribadian matang, mampu membangun dan memperkuat diri dalam menumbuhkan sikap mental positif. Karena pada dasarnya raga setiap individu dipengaruhi oleh 4 hal yang saling berkaitan yaitu: aql, nafs, qalb dan ruh.
\end{abstract}

Kata kunci: REBT Islam, Sikap Mental Positiif

\begin{abstract}
Islamic Rational Emotive Behavior Therapy (REBT) in Fostering Positive Mental Attitudes. This study aims to describe the Islamic REBT theory in fostering a positive mental attitude. The method used in this research uses literature study sourced from books, scientific articles, websites, and similar previous research results and can be used to get a theoretical basis for the problem to be studied. The results of the analysis explain that the implementation of the REBT theory contained in Islamic values can make individuals have healthy personalities and will make individuals have mature personalities, able to build and strengthen themselves in fostering positive mental
\end{abstract}


attitudes. Because basically the body of each individual is influenced by 4 related things, namely: aql, nafs, qalb and spirit.

\section{Keywords: Islamic REBT, Positive Mental Attitude}

\section{A. Pendahuluan}

Kesehatan mental merupakan aspek penting dalam mewujudkan kesehatan secara menyeluruh. Kesehatan mental juga penting diperhatikan selayaknya kesehatan fisik. Individu yang berpikir positif akan melihat setiap kesulitan dengan cara yang gamblang dan polos serta tidak mudah terpengaruh, sehingga tidak mudah putus asa jika dihadapkan dengan berbagai tantangan ataupun hambatan dalam hidupnya. Individu yang berpikir positif selalu didasarkan fakta bahwa setiap masalah pasti ada pemecahan dan suatu pemecahan yang tepat selalu melalui proses intelektual yang sehat (Peale, 2009: 18).

Dalam mengenal adanya gangguan pada mental seseorang tidak semudah seperti halnya pada gangguan fisik. Pada dasarnya banyak faktor yang mempengaruhi kesepakatan pengertian terhadap gangguan mental tersebut. Selain karena faktor kultural yang mengartikan konsep sehat dan sakit secara berbeda antara budaya satu dengan lainnya, juga faktor individual yaitu persepsi dan perasaan yang sangat subjektif sifatnya.

Rasa sedih, kecewa, marah, takut dan lain-lain adalah sesuatu yang sebenarnya muncul dari setting dan pola pikir yang telah terbentuk. Begitu pula sebaliknya, rasa bahagia, senang, gembira, berharga, dicintai, dan lain-lain merupakan hasil dari pola berpikir dan setting dari pikiran yang telah terbentuk. Individu yang menginginkan hidupnya bahagia, tentunya harus membentuk pola pikirnya menjadi pola pikir yang positif. Artinya proses kognitif memainkan peran sangat penting dalam mengatur kecemasan dan kebahagiaan pada seseorang Selain itu, proses berpikir sangatlah penting karena berhubungan dengan perilaku dan berbagai keberhasilan hidup seseorang (Rusydi, 2012: 2). 
Pemahaman sikap mental positif tidak terlepas dari pemahaman mengenai mental yang sehat. Berbagai penelitian telah mengungkapkan adanya hubungan antara sikap mental positif dengan mental yang sehat. World Helath Organization (WHO) mengatakan bahwa seseorang yang memiliki mental yang sehat di dalam dirinya terdapat kemampuan-kemampuan untuk mengelola stress kehidupan yang wajar, untuk bekerja secara produktif dan menghasilkan, serta berperan dalam komunitasnya (Ayuningtyas et al., 2018: 5).

Eric Fromm menjelaskan bahwa manusia yang berkepribadian sehat adalah manusia yang berkarakter produktif, yaitu mereka yang mampu mengembangkan potensi, memiliki cinta kasih, imaginasi, serta kesadaran diri yang baik. Sedangkan menurut Allport, individu berkepribadian sehat diistilahkan dengan mature personality, yang memiliki kemampuan mengembangkan dirinya, memiliki hubungan interpersonal yang baik, realistis, memiliki filosofi hidup, serta bersikap berani dan objektif terhadap diri sendiri (Dewi, 2012: 75). Individu yang memiliki kepribadian sehat dengan sendirinya akan menjadi individu yang memiliki kepribadian yang matang, mampu membangun dan memperkuatnya dirinya dalam sikap mental positif.

Seringkali kita berpikir namun tidak berpikir positif atau dengan kata lain berpikir negatif. Sehingga kadang kita menyiksa diri kita sendiri dengan pikiranpikiran negatif tersebut. Berpikir positif dapat dideskripsikan sebagai suatu cara berpikir yang lebih menekankan pada sudut pandang dan emosi yang positif, baik terhadap diri sendiri, orang lain maupun situasi yang dihadapi (Elfiky, 2014: 65). Berpikir positif pun merupakan suatu kebiasaan untuk melihat segala sesuatu yang dihadapi atau diamati dari segi positif dan membiarkan pikirannya berproses secara positif yang kemudian mempengaruhi sikap dan prilaku.

Menurut Williams, pola pikir positif merupakan kecenderungan individu untuk memandang segala sesuatu dari segi positifnya dan selalu berpikir optimis terhadap lingkungan serta dirinya sendiri. Pola pikir inilah yang dapat membantu individu dalam mengatasi masalahnya. Seligman, menjelaskan bahwa orang yang 
berpikir positif cenderung menafsirkan permasalahan mereka sebagai hal yang sementara, terkendali, dan hanya khusus untuk satu situasi, orang yang berpikir negatif sebaliknya yakin bahwa permasalahan mereka berlangsung selamanya, menghancurkan segala yang mereka lakukan dan tidak terkendali. Dengan berpikir positif, individu akan mudah menyelesaikan beragam masalah dan tugas yang dihadapi, serta memberikan sugesti positif pada diri ketika mengalami kegagalan dan dapat membangkitkan motivasi (Hill \& Ritt, 2004: 65).

Berpikir positif akan menjadikan individu lebih optimis menghadapi hidup dan memudahkan individu untuk beraktivitas dengan baik. Individu yang tidak mampu berpikir positif akan merasakan kesulitan dalam hidup, karena keyakinan dan konsep yang salah serta negatif mengenai hidupnya dan lingkungannya. Karena itu individu yang berpikir positif cenderung lebih optimis dalam menjalani hidup, adapun individu yang tidak berpikir positif akan sulit dalam menjalani hidup dan tentunya ini akan berdampak pada permasalahan mental bahkan fisik. Maka orang yang optimis cendeurng menunjukkan kepuasan hidup yang lebih baik (Lin et al., 2010).

Agama dipandang sebagai dampak yang cukup berarti dalam kehidupan manusia, termasuk terhadap kesehatan. Orang yang sehat mental akan senantiasa merasa aman dan bahagia dalam kondisi apapun, ia juga akan melakukan introspeksi atas segala hal yang dilakukannya sehingga ia akan mampu mengontrol dan mengendalikan dirinya sendiri. Solusi terbaik untuk dapat mengatasi masalahmasalah kesehatan mental adalah dengan mengamalkan nilai-nilai agama dalam kehidupan sehari-hari, kesehatan mental seseorang dapat ditandai dengan kemampuan orang tersebut dalam penyesuaian diri dengan lingkungannya, mampu mengembangkan potensi yang terdapat dalam dirinya sendiri semaksimal mungkin untuk menggapai ridho Allah SWT, serta dengan mengembangkan seluruh aspek kecerdasan, baik kesehatan spiritual, emosi maupun kecerdasan intelektual (Hamid, 2017). 
Agama islam memandang bahwa seseorang dikatakan memiliki mental yang sehat ditandai dengan konsep kebahagiaan. Sumber kebahagiaan manusia datang dari dua arah, yaitu dari manusia dan dari Tuhan. Jadi, kesehatan mental adalah dimana seseorang mampu beradaptasi dengan lingkungan dan orang-orang disekitarnya mampu membuat bahagia diri sendiri dan orang lain (Fitrianah, 2018).

Menurut Maslow dan Mitelmann, individu yang normal dengan mental yang sehat memiliki kriteria, antara lain: (1) Memiliki perasaan aman, (2) Memiliki penilaian diri dan wawasan rasional, (3) Mempunyai kontak dengan realitas secara efisien, (4) Memiliki dorongandorongan dan nafsu-nafsu jasmaniah yang sehat, serta memiliki kemampuan untuk memenuhi dan memuaskanya, (5) Mempunyai pengetahuan diri yang cukup, (6) Mempunyai tujuan hidup yang adekuat, (7) Memiliki kemampuan untuk belajar dari pengalaman hidupnya, (8) Ada kesanggupan untuk memuaskan tuntutan-tuntutan dan kebutuhankebutuhan dari kelompoknya, (9) Ada sikap emansipasi yang sehat terhadap kelompoknya dan terhadap kebudayaan, (10) Ada integrasi dalam kepribadiaannya, dan Memiliki spontanitas dan emosionalitas yang tepat (Reza, 2015).

Dalam pendekatan konseling REBT mengintegrasikan materi keagamaan dengan Intervensi Rasional Emotif yang dapat membuat hidup klien sangat pribadi, kuat, dan mendalam khususnya bagi klien yang religious (beragama). Sebagai seorang konselor REBT tidak diperkenankan mengakomodasi keyakinan agama konselor kepada klien selama terapi, berikan kebebasan kepada klien untuk mengintegrasikan keyakinan agamanya. REBT pada dasarnya adalah psikoterapi konstruktivis, sangat akomodatif dan integratif dari nilai dan keyakinan klien, termasuk keyakinan agama. REBT menekankan pada pencarian keyakinan yang inti, memungkinkan untuk fokus dalam kesederhanaan dan keanggunan yang netral dengan menghormati sebagian besar hal khusus dalam situasi klien, termasuk halhal khusus dari keyakinan agama klien (Bastomi \& Aji, 2018).

Berdasarkan teori REBT, perwujudan sistem nilai dan kepercayaan yang salah dan tidak rasional dalam diri manusia adalah sebab utama menjadikan 
seseorang itu merasa tertekan dan dapat menimbulkan pelbagai masalah kepada individu tersebut. Pemikiran yang tidak rasional ini perlu dirubah dan dibetulkan agar ia dapat terpandukan dengan nilai-nilai yang baik dan rasional (Masroom et al., 2015). Dalam pandangan Rational Emotive Behaviour Teraphy (REBT) bahwa manusia memiliki potensi yang bisa berkembang dan dapat dikembangkan. Dalam hal ini agama Islam telah mengedepankan argumen dan memandang bahwa manusia terlahir dengan sempurna, suci (fitrah) dan memiliki konsep hidup yang matang bahwa manusia itu memiliki potensi berfikir serta berakal.

Konteks adanya perilaku positif dan negatif yang terkandung dalam Rational Emotive Behaviour Teraphy (REBT) sudah dijabarkan sebelumnya dalam Islam yakni Nafs Zakiyah dan Nafs Ammarah bissu'i. Yang dimaksud dengan nafs zakiyyah (positif) diri manusia yang suci dan tidak terkontaminasi dengan apapun juga, yang menyebabkan manusia itu berfikir yang negatif serta melakukan perbuatan yang dianggap merusak kehidupannya selama di dunia ini. Sedangkan nafs ammarah bissu'i (negatif) adalah yang selalu cenderung melakukan perbuatan buruk, yang menyebabkan dirinya terjerumus terhadap perilaku yang menyimpang dari ajaran agama Islam.

Dengan demikian untuk mengaktifkan dan menumbuhkan kembali sikap mental positif perlunya pemahaman yang mendalam bagi individu. REBT atau yang lebih dikenal dengan Rational Emotive Behaviour Therapy adalah konseling yang menekankan interaksi berfikir dan akal sehat (rational thingking), perasaan (emoting), dan berperilaku (acting). Teori ini menekankan bahwa suatu perubahan yang mendalam terhadap cara berpikir dapat menghasilkan perubahan yang berarti dalam cara berperasaan dan berperilaku, sehingga seseorang akan memiliki kepercayaan diri dan mampu memecahkan masalah serta memiliki tujuan hidup yang berarti bagi orang lain. 


\section{B. Metode}

Penelitian ini menggunakan pendekatan Studi Kepustakaan (Library Research). Studi kepustakaan merupakan suatu studi yang digunakan dalam mengeumpulkan informasi dan data dengan bantuan berbagai macam material yang ada di perpustakaan seperti dokumen, buku, majalah, kisah-kisah sejarah, dsb (Mardalis, 1999: 79).

Studi kepustakaan juga dapat mempelajari berbagai buku referensi serta hasil penelitian sebelumnya yang sejenis yang berguna untuk mendapatkan landasan teori mengenai masalah yang akan diteliti (Sarwono: 2006). Studi kepustakaan juga berarti teknik pengumpulan data dengan melakukan penelaahan terhadap buku, literatur, catatan, serta berbagai laporan yang berkaitan dengan masalah yang ingin dipecahkan (Nazir: 1988). Sedangkan menurut ahli lain studi kepustakaan merupakan kajian teoritis, referensi serta literatur ilmiah lainnya yang berkaitan dengan budaya, nilai dan norma yang berkembang pada situasi sosial yang diteliti (Sugiyono: 2012). Adapun langkah-langkah dalam penelitian kepustakaan menurut Kuhlthau (2002) adalah sebagai berikut : (1) Pemilihan topic, (2) Eksplorasi informasi, (3) Menentukan fokus penelitian, (4) Pengumpulan sumber data, (5) Persiapan penyajian data dan (6) Penyusunan laporan. Sumber data dalam penelitian bersumber dari: buku, jurnal dan situs internet yang terkait dengan topik REBT dlama menumbuhkan sikap mental positif.

\section{Pembahasan}

\section{Definisi Sikap Mental Positif}

Sikap mental positif adalah keadaan dimana jiwa seseorang memiliki rasa percaya diri, jujur, dan membangun untuk membangkitkan kesuksesan. Konsep Sikap Mental Positif pertama kali diperkenalkan dan dikembangkan oleh Napoleon Hill, seorang penulis asal Amerika Serikat yang mengkhusukan diri menulis tentang self-development yang lebih mempelajari kekuatan keyakinan pribadi dan peran yang dimainkannya dalam menempuh kesuksesan pribadi. 
Menurut Hill, sikap mental positif adalah sikap mental psikologis yang dapat membangkitkan rasa ingin berhasil lewat sifat optimistik. Hal ini akan membawa pemikiran mereka yang menganutnya untuk mengatasi masalah yang tengah dihadapinya (Paksi, 2016: 143).

Sikap mental mengontrol tempat kediaman seseorang dalam hidupnya, sukses yang diraih seseorang, teman-teman yang dimiliki, dan kontribusi yang diberikan kepada anak cucu. Menurut Hill, ada tiga motivasi utama untuk berusaha untuk memiliki sikap mental positif, yaitu cinta, seks, dan uang. Tiga motivasi utama itu timbul dalam diri seseorang, tapi masih ada motivasi yang timbul karena orang lain, yaitu hubungan dengan orang lain yang memiliki pikiran positif. Menurut Ubaedy dan Imam sikap mental adalah bagaimana seseorang dapat melihat fakta atau kenyataan hidup yang menimpa kita. Sikap mental akan bepengaruh pada kualitas hasil atau sebagus apa kita akan bertindak terhadap masalah yang menimpa kita (An Ubaedy, 2015: 92).

Menurt Fattah Hanurawan (2012) Pemahaman sikap mental positif yang tidak terlepas dari pemahaman mental yang sehat tidak terlepas dari ciri-ciri yang sama. Ciri-ciri itu adalah sebagai berikut:

a. Seseorang yang memiliki perasaan bahagia dan kepuasan dalam menjalani kehidupan.

b. Seseorang memiliki semangat dalam menjalani kehidupan (kemampuan untuk menikmati hidup, keceriaan, dan kesenangan-kesenangan yang lain).

c. Seseorang yang memiliki daya hidup (elanvital) dalam menghadapi stress hidup dan bangkit dari kegagalan-kegagalan hidup yang dialami.

d. Seseorang memiliki kemampuan untuk merealisasikan diri. Kemampuan realisasi diri adalah kemampuan berpartisipasi dalam hidup sesuai dengan potensi-potensi terbaik yang ada dalam dirinya melalui aktivitas-aktivitas hidup yang bermakna dan hubungan sosial yang positif. 
e. Seseorang memiliki kemampuan fleksibilitas. Kemampuan fleksibilitas adalah kemampuan untuk berubah, berkembang, dan mengalami berbagai variasi perasaan sejalan dengan variasi perubahan kondisi kehidupan.

f. Seseorang memiliki perasaan tentang keseimbangan hidup. Keseimbangan hidup misalnya adalah antara keseimbangan privasi dan sosialitas, bermain dan bekerja, tidur dan bangun, serta istirahat dan beraktivitas.

g. Seseorang memiliki perhatian kepada diri sendiri dan orang lain.

h. Seseorang memiliki kepercayaan diri dan penilaian diri yang baik kepada diri sendiri.

Selain ciri-ciri yang telah diuraikan di atas, terdapat juga model ciri-ciri sikap mental positif lain yang dikemukakan oleh Myers, Sweener, dan Witmer dikutip Fattah. Model ini menjelaskan bahwa orang yang memiliki sikap mental positif adalah mampu memenuhi beberapa tugas dan sub tugas dalam segenap aktivitas hidupnya. Tugas-tugas itu antara lain seperti memahami esensi spiritualitas, keseimbangan antara bekerja dan memanfaat waktu luang, mengembangkan persahabatan, mengembangkan cinta, dan mandiri. Sedangkan sub tugasnya adalah memiliki perasaan berarti kepada diri sendiri, memiliki perasaan kontrol, memiliki keyakinan yang bersifat realistis, kesadaran emosi dan koping, pemecahan masalah dan kreativitas, memiliki perasaan humor, memperoleh nutrisi yang cukup, melakukan olahraga, memiliki perhatian kepada diri sendiri, memiliki kemampuan mengelola stres, dan memiliki kesadaran tentang budaya (Wikipedia, 2008).

\section{Menumbuhkan Sikap Mental Positif}

Dalam menumbuhkan sikap mental positif dapat dilakukan dengan berbagai cara. Hal terbaik untuk melakukannya adalah dengan pembiasaan diri. Karena pengulangan yang berkelanjutan dan tahapan-tahapan yang dilalui seperti berpikir, perekaman, pengulangan dan penyimpanan yang dilalui seseorang, akal 
manusia meyakini bahwa kebiasaan ini merupakan bagian terpenting dari perilaku seseorang tersebut.

Pertama, sebelum melakukan kebiasaan yang akan mengubah sikap mental seseorang, hendaknya orang tersebut mampu menghargai diri sendiri terlebih dahulu dengan cara orang tersebut mampu untuk menerima diri sendiri, mempunyai harga diri, dan mencintai diri sendiri. Kedua, berpikir positif. Pada dasarnya pikiran manusia mampu mempengaruhi seluruh aspek pada dirinya sendiri mulai dari berpikir, konsentrasi, perasaan, sikap, sampai hasil. Kekuatan dari pikiran dan pengaruhnya terhadap akal akan membuat seseorang berkonsentrasi pada sesuatu hingga melahirkan perasaan tertentu dalam diri seseorang, perasaan inilah yang akan mendorong seseorang untuk bersikap. Begitulah proses berpikir yang menjadi mata rantai dalam menghasilkan sesuatu di kehidupan seseorang.

Ketiga, beriman, memohon bantuan, dan tawakal kepada Allah. Dari segi agama sikap mental positif adalah yang seseorang yang tidak luput untuk beriman kepada Allah, tawakal kepada-Nya, dan meminta pertolongan kepada-Nya di setiap waktu. Keempat, selalu memegang nilai-nilai luhur. Sikap mental positif akan bertahan sebesar apapun pengaruh dan godaan, ia akan selalu menjauh dari sikap negatif. Seseorang yang mempunyai sikap mental positif selalu mengedepankan kejujuran, amanah, menyukai kebaikan, murah hati, bergantung kepada Allah, dan selalu meneladani akhlak Rasulullah SAW dan orang-orang saleh.

Kelima, selalu belajar dari masalah dan kesulitan. Individu yang mempunyai mental positif tidak hanya belajar untuk memecahkan masalah, tapi juga dapat mengambil pelajaran dari setiap masalah yang dihadapi. Individu tersebut tidak akan rela membiarkan masalah dan kesulitan yang menghampirinya mempengaruhi aspek kehidupan yang lain. Ia harus mampu menyikapi segala masalah dengan wajar dan tiak berlebihan (Elfiky, 2014: 55).. Keenam, mempunyai keyakinan terhadap diri sendiri untuk mencapai suatu hasil. 
Keyakinan kemampuan seseorang dapat membantu menentukan hasil yang diharapkan, karena individu memiliki confident dalam mengantisipasi hasil yang sukses. Perasaan yakin yang kuat dapat meningkatkan kecapakan seseorang dan kesejahterannya dalam cara yang tak terbayangkan. Individu yang berkeyakinan kuat, memandang tugas-tugas yang sulit sebagai tantangan untuk dikuasai daripada sebagai ancaman untuk dihindari.

Selanjutnya yang terakhir dengan memperluas pergaulan dengan orangorang yang berpikiran positif. Melalui pergaulan dengan orang-orang yang memiliki minat atau bidang pekerjaan yang sama, semangat seseorang akan semakin terpacu untuk berkompetensi dengan mereka. Perlunya bergaul dengan orang-orang yang berpikiran positif menurut David J. Schwartz dapat menstimulasi sikap mental seseorang yang diibaratkan bahwa pikiran yang hanya mendapat makanan dari dirinya sendiri akan segera kekurang gizi, menjadi lemah, dan tidak mampu berpikir kreatif dan progresif oleh karena itu stimulasi dari orang lain adalah makanan pikiran yang sangat bagus untuk didapatkan (Paksi, 2016: 78).

Menurut Gilbert dalam penelitiannya menemukan bahwa orang yang memiliki sikap mental positif akan dapat merasakan lebih rileks dan dapat mengontrol stress dengan lebih baik. Sikap mental positif akan menjadikan seseorang lebih optimis menghadapi hidup dan memudahkan seseorang untuk beraktivitas dengan baik. Seseorang yang tidak mempunyai sikap mental positif akan merasakan kesulitan dalam hidupnya, karena keyakinan dan konsep yang salah dan negatif mengenai hidupnya dan lingkungannya. Maka orang yang optimis cenderung menunjukkan kepuasan hidup yang lebih baik (Rusydi, 2012).

Dalam teori psikodinamik menjelaskan bahwa individu yang memiliki sikap mental positif akan mampu untuk mencintai dan bekerja. Kemudian individu tersebut juga memiliki ego strength yang artinya memiliki kekuatan mengendalikan dan mengatur id dan super egonya, sehingga ekspresi primitif id berkurang dan ekspresi yang sesuai dengan situasi yang muncul tanpa adanya 
represi dari ego secara berlebihan. Individu yang memiliki sikap mental positif akan menghasilkan individu yang kreatif sehingga memiliki kekuaan untuk mengarahkan perilaku mengembangkan potensi yang dimilikinya. Manfaat lainnya adalah individu akan menyadari adanya ketidaksempurnaan pada dirinya dan mampu mengembagkan potensi yang ada untuk mengimbangin kekurangannya, selanjutnya individu tersebut akan memiliki hasil yang positif dalam setiap tahap interaksinya dengan lingkungan social (Dewi, 2012: 76).

\section{Rational-Emotif Behavior Therapy (REBT) ISLAM}

Asal-usul rasional-emotif behavior therapy dapat ditelusuri dengan filosofi dari Stoicisme di Yunani kuno yang membedakan tindakan dari interpretasinya. Epictetus dan Marcus Aurelius dalam bukunya "The Enchiridion", menyatakan bahwa manusia tidak begitu banyak dipengaruhi oleh apa yang terjadi pada dirinya, melainkan bagaimana manusia memandang/menafsirkan apa yang terjadi pada dirinya.

Manusia lahir dengan potensi untuk berfikir secara rasional dan tidak rasional. Tidak ada seorang manusia yang terkecuali dari pemikiran rasional termasuk terapis Secara khusus pendekatan terapi rasional emotif behavior berasumsi bahwa individu memiliki karakteristik sebagai berikut: Individu memiliki potensi yang unik untuk berfikir rasional dan irasional, pikiran irasional berasal dari proses belajar yang irasional yang didapat dari orang tua dan budayanya, manusia adalah makhluk verbal dan berfikir melalui simbol dan bahasa, gangguan emosional yang disebabkan oleh verbalisasi diri (self verbalizing) yang terus menerus dan persepsi serta sikap terhadap kejadian merupakan akar permasalahan, bukan karena kejadian itu sendiri, individu memiliki potensi untuk mengubah arah hidup personal dan sosialnya, serta pikiran dan perasaan yang negatif dan merusak diri dapat diserang dengan mengorganisasikan kembali persepsi dan pemikiran, sehingga menjadi logis dan rasional (Bradley \& Sutjipt, 2016: 269). 
Rational Emotive Behavior Therapy (REBT) berbasis Islam lahir sebagai upaya membantu memberdayakan kembali potensi yang ada di dalam diri individu yaitu fitrah manusia yang telah diberikan aql, qalb, nafs, dan ruh serta kembali mengaktifkan keimanan dan ketakwaan hingga kembali berkembang dan berfungsi sebagaimana mestinya.

1. Aql selalu berkaitan dengan etika memberikan sebuah makna bahwa dengan berfikir rasional individu akan menyadari konsekuensikonsekuensi perbuatan dan pengaturan pengontrolan dorongan emosionalnya dipandang dari sudut tinjauan masa depan (Abdullah, 2002: 14).

2. Qalb sebab berfungsi sebagai penggerak dan pengontrol anggota tubuh lainnya. Hal ini berdasarkan hadits yang diriwayatkan oleh Imam Bukhari dan Muslim yang artinya: "Ingatlah bahwa di dalam tubuh terdapat sepotong daging. Apabila ia baik, maka baiklah badan itu seluruhnya dan apabila ia rusak, maka rusaklah badan itu seluruhnya. Ingatlah sepotong daging itu adalah hati".

3. Nafs merupakan suatu perasaan halus (lathifah), yaitu jiwa manusia dan substansinya, tetapi berbeda-beda sesuai dengan ahwal (kondisi-kondisi ruhani) masing-masing. Kecenderungan nafs adalah memaksakan hasrathasratnya dalam upaya untuk memuaskan diri. Sedangkan akal berperan sebagai kekuatan pembatas sekaligus penasihat bagi nafs, memberikan pertimbangan kepada nafs tentang tindakan-tindakan positif yang seharusnya dilakukan dan tindakantindakan negatif yang harus dihindari.

4. Ruh adalah cahaya halus pada diri manusia yang dengannya ia dapat mengetahui dan mengidrak sebagaimana fungsi kalbu dan ruh inilah merupakan hakikat hati. (Sri Hartati, Imas Kania Rahman, 2017: 21)

Dari Uraian di atas dapat disimpulkan bahwa raga pada setiap individu dikendalikan oleh aql dan nafs yang keduanya terletak di dalam qalb yang dapat hidup karena adanya ruh dengan kuasa Allah SWT. Fitrah manusia di hadapan 
Allah SWT ditunjukkan melalui cara manusia dalam berpikir secara rasional dan menyadari bahwa dengan menjalankan segala perintah yang ditetapkan dalam ajaran al-Qur’an dan Hadits dan menjauhi segala bentuk larangan Allah dengan tujuan untuk memperoleh keselamatan di dunia dan di akhirat.

\section{Implementasi REBT Islam Terhadap Sikap Mental Positif}

Rational Emotive Behavior Therapy berbasis islam lahir sebagai upaya membantu memberdayakan kembali potensi yang ada di dalam diri individu yaitu manusia fitrah dan kembali mengaktifkan keimanan dan ketakwaan hingga kembali berkembang dan berfungsi sebagaimana mestinya. Teknik REBT dan sikap mental positif saling terkait karena di dalam kedua hal tersebut sama-sama menekankan adanya 'self-acceptence', yang mana jika hal tersebut tidak terpenuhi terlebih dahulu maka proses untuk mendapatkan sikap mental positif tidak akan tercapai sebagaimana mestinya. Dalam teori REBT Ellis memiliki keyakinan bahwa setiap manusia secara natural dapat menjadi orang yang mampu menolong dan mencintai sepanjang mereka tidak berpikir irasional.

Menjadi individu yang tidak pernah merasakan masalah adalah hal tidak mungkin terjadi di dunia ini. Berbagai masalah muncul dan menjadikan hari-hari kita tidak menyenangkan, di mana semuanya seperti tidak berjalan lancar yang berujung pada sikap negatif. Padahal seseorang dapat menjadi sukses selain mempunyai kecerdasan dan kemampuan dalam kehidupannya, hal yang paling mendasar sebelum itu semua sebenarnya adalah sikap mental positif.

Menumbuhkan sikap mental positif memang tidak mudah, karena membutuhkan kesadaran akan pentingnya sikap positif. Tetapi dalam menerapkan sikap mental positif dalam kehidupan sehari-hari dapat dilakukan dengan berbagai cara seperti memberikan kebebasan pada diri untuk mengontrol hidup, mempercayai perubahan kearah yang lebih baik, menerima kritik, saran dan tantangan yang muncul dari berbagai sisi dan mengubahnya menjadi 
semangat positif, selanjutnya individu juga dapat belajar dari pengalaman dan fokus ke masa depan, dan bersyukur terhadap segala sesuatu yang telah dimiliki.

REBT Islam adalah sebuah pendekatan konseling mengakomodasi keyakinan agama klien bahkan ketika klien dan terapis memiliki orientasi keagamaan yang sangat berbeda yang berfokus pada keyakinan (agama Islam) yang mana keyakinan agama klien dapat memberikan struktur penting kepada skema pengorganisasian kepribadian klien. Maka REBT Islami sangat cocok untuk mengintegrasikan keyakinan agama klien dalam intervensi konseling dalam menumbuhkan sikap mental positif. Dalam pendekatan konseling REBT mengintegrasikan materi keagamaan dengan Intervensi konseling yang dapat membuat hidup klien sangat pribadi, kuat, dan mendalam khususnya bagi klien yang religious (beragama). Selanjutnya Sebagai seorang konselor REBT tidak diperkenankan mengakomodasi keyakinan agama konselor kepada klien selama terapi, berikan kebebasan kepada klien untuk mengintegrasikan keyakinan agamanya (Bastomi \& Aji, 2018).

Oleh karena itu individu yang mengalami masalah dalam kehidupannya sehingga melahirkan sikap mental negatif dalam konsep bimbingang konseling sejalan dengan tujuan teori rational emotif behavior therapy. Dengan menggunakan teknik REBT dalam proses konseling diharapkan individu yang mengalam masalah tersebut dapat meningkatkan kesadaran dan minat pada diri sendiri, minat sosial, pengarahan diri yang lebih baik, dam toleransi kepada orang lain sehingga mengembalikan dirinya dalam menghasilkan sikap mental positif dalam kehidupannya. Dengan implementasi teori REBT nilai yang terkandung dalam Islam dapat menjadikan Individu yang memiliki kepribadian sehat dan akan menjadikan individu memiliki kepribadian matang, mampu membangun dan memperkuatnya dirinya dalam sikap mental positif. 


\section{Simpulan}

Berdasarkan uraian diatas dapat ditarik kesimpulan bahwa raga pada setiap individu dipengaruhi oleh 4 hal yang saling berkesinambungan yaitu: Aql, nafs, qalb, dan ruh. Dalam menerapkan sikap mental positif dalam kehidupan sehari-hari dapat dilakukan dengan berbagai cara seperti memberikan kebebasan pada diri untuk mengontrol hidup, mempercayai perubahan kearah yang lebih baik, menerima kritik, saran dan tantangan yang muncul dari berbagai sisi dan mengubahnya menjadi semangat positif, selanjutnya individu juga dapat belajar dari pengalaman dan fokus ke masa depan, dan bersyukur terhadap segala sesuatu yang telah dimiliki. 


\section{DAFTAR PUSTAKA}

Abdullah, A. (2002). Filsafat Etika Islam. Mizan.

An Ubaedy, R. (2015). Refleksi Kehidupan. Elex Media Komputindo.

Ayuningtyas, D., Misnaniarti, \& Rayhani, M. (2018). ANALISIS SITUASI KESEHATAN MENTAL PADA MASYARAKAT DI INDONESIA DAN STRATEGI PENANGGULANGANNYA. Jurnal Ilmu Kesehatan Masyarakat, 9 (1).

Bastomi, H., \& Aji, M. A. S. (2018). Konseling Rational Emotif Behaviour Theraphy (Rebt)-Islami (Sebuah Pendekatan Integrasi Keilmuan). KONSELING EDUKASI : Journal Of Guidance And Counseling, 2, No 2.

Bradley, T. E., \& Sutjipt, H. P. (2016). 40 Teknik Yang Harus Diketahui Setiap Konselor. Pustaka Pelajar.

Dewi, K. S. (2012). Kesehatan Mental. UPT UNDIP Press.

Elfiky, I. (2014). Terapi Berpikir Positif. Zaman.

Fitrianah, R. D. (2018). Keseimbangan Emosi Dan Kesehatan Mental Manusia Dalam Persfektif Psikologi Agama. Syi'ar, 18 No. 1.

Hamid, A. (2017). Agama dan Kesehatan Mental Dalam Perspektif Psikologi Agama. Jurnal Kesehatan Tadalako, Vol. 3, No.

Hanurawam, F. (2012). Strategi Pengembangan Kesehatan Mental di Lingkungan Sekolah. Psikopedagogik, No. 1.

Hill, N., \& Ritt, M. J. (2004). Keys To Positive Thinking. Bhuana Ilmu Populer.

Lin, M., Chiang, Y., \& Liu, H. E. (2010). The Relationship Between Optimism and Life Satisfaction for Patients Waiting or Not Waiting for Renal Transplantation. Transplantation Proceedings, 42, No. 3.

Mardalis. (1999). Metode Penelitian Suatu Pendekatan Proposal. Bumi Aksara.

Masroom, M. N., Muhamad, S. N., \& Rahman, S. A. A. (2015). Kesihatan Mental, REBT dan Muslim. Sains Humanika, 6 (1).

Paksi, Y. J. (2016). Berpikir Positif Dan Berjiwa Besar. Cakrawala.

Peale, N. . (2009). The Power of Positive Thinking. Ragam Media.

Reza, I. F. (2015). , Efektivitas Pelaksanaan Ibadah Dalam Upaya Mencapai Kesehatan Mental. Jurnal Psikologi Islam, 1, No. 1.

Rusydi, A. (2012). Husn Al-Zhann: Konsep Berpikir Positif Dalam Perspektif Psikologi Islam Dan Manfaatnya Bagi Kesehatan. Jurnal Proyeksi, 7, No. I.

Wikipedia. (2008). Mental Healt. Wikipedia.Org. https://en.wikipedia.org/wiki/Mental_health 
